\title{
MOLECULAR CHARACTERIZATION AND PRODUCTION OF BACTERIAL AMYLASES FROM SHAHDARA SPRING, PAKISTAN
}

\author{
AFRIDI, S. $.^{1 \dagger}-$ ALI, N. ${ }^{2,3{ }^{* *}}-$ NIAZ, M. ${ }^{1}-$ HUSSAIN, S. I. ${ }^{2}-$ FARMAN, F. U. ${ }^{4}-$ KIM, B. C. ${ }^{3 *}$ \\ ${ }^{I}$ Department of Microbiology, Kohat University of Science \& Technology (KUST), 26000 \\ Kohat, Pakistan \\ ${ }^{2}$ Department of Biotechnology and Genetic Engineering, Kohat University of Science \& \\ Technology (KUST), 26000 Kohat, Pakistan \\ ${ }^{3}$ Division of Nano-Bioengineering, Incheon National University, Incheon 22012, Republic of \\ Korea \\ ${ }^{4}$ Department of Chemistry, Kohat University of Science \& Technology (KUST), 26000 Kohat,
} Pakistan

${ }^{\dagger}$ These authors have contributed equally to this work

*Corresponding authors

e-mail:nawabali_1857@yahoo.com,introbc@gmail.com

(Received $27^{\text {th }}$ Jul 2019; accepted $30^{\text {th }}$ Jan 2020)

\begin{abstract}
Microorganisms are the preferred source of enzyme applicable to a variety of industries, such as food, paper, detergent, and energy. In this study, amylase enzymes were explored for the first time in the springs of Shahdara, Islamabad, Pakistan. 22 out of 28 bacterial isolates showed amylase activity from which the three best amylase producing isolates (S5, S13, and S17) were selected for further studies. These isolates were identified as Bacillus spp and Clostridium spp using microscopic, biochemical, and molecular-based (16S rRNA) approaches. Phylogenetic analysis further revealed that strains (S5, S13, and S17) have 97\% similarity with Paraclostridium benzoelyticum, Bacillus subtilis, and Bacillus tequilensis, respectively. The maximum amylase production of Bacillus subtilis and Paraclostridium benzoelyticum was observed at $\mathrm{pH} 5$ and $55^{\circ} \mathrm{C}$ whereas that of Bacillus tequilensis was at $\mathrm{pH} 8$ and $55^{\circ} \mathrm{C}$. Similarly, the highest activity of amylases from each strain was found at $55{ }^{\circ} \mathrm{C}$ in common, but in different $\mathrm{pH}$ conditions (at $\mathrm{pH} 5$ for Paraclostridium benzoelyticum and Bacillus subtilis and at $\mathrm{pH}$ 6-8 for Bacillus tequilensis). Our study represents that Shahdara springs have beneficial microbial reservoirs producing acidic and thermostable amylases, having great importance to various bio-industrial applications.
\end{abstract}

Keywords: thermostable amylase, Shahdara springs, Bacillus spp, Clostridium spp, 16S rRNA gene sequencing

\section{Introduction}

Microbial enzymes are preferred natural sources to animals and plants due to the ease of cultivation, shorter generation time, low cost, and feasibility for human consumption. Microorganisms, which synthesize the microbial enzymes, are found in different sources including extreme sites such as springs, salt mines, and deserts. Among them, springs are considered the best natural source of microbial enzymes. It provides suitable environments for various extremophiles including thermophiles, acidophiles, and alkaliphiles that produce extremophilic enzymes (Sen et al., 2010), which collectively have attracted researchers' attention (Ali et al., 2013; Tango and Islam, 2002). The 
extremophilic enzymes gathered from springs, in particular, have a great potential for many industrial applications because of their diversity and unique enzyme activity (Gopinath et al., 2017; Li et al., 2012; Singh et al., 2016).

Among these enzymes, amylases, which can be used to hydrolyze starch into dextrin and small polymers of glucose, are the most widely used enzymes in various industries, taking the first place in the global enzyme market (25-33\%). Amylases have replaced acidic hydrolysis and chemical catalysts for starch degradation which is available in huge amounts in waste reservoirs (Sen et al., 2014). Amylases have many applications in the food and pharmaceutical industries such as production of fruit juices, bread making, glucose syrups and alcoholic beverages (Wajeeha et al., 2011). Amylases are generally classified into 1$)$ endoamylases ( $\alpha$-amylases), 2$)$ exoamylases ( $\beta$-amylase, glucoamylase), and 3) debranching enzymes (pullulanase, isoamylase) based on their modes of action to generate glucose, maltose, malto-oligosaccharides, and dextrins (Kim and Toldrá, 2016; Suriya et al., 2016). Amylase enzymes have diverse bioindustrial applications which demand large scale exploration of these enzymes in extreme reservoirs (de Souza and de Oliveira Magalhaes, 2010; Parmar and Pandya, 2012; Patel et al., 2018). Pakistan is particularly gifted with a number of extremophilic environments. Several hot springs, salt mines, deserts, glaciers, marine brine pools, and hydrothermal vents are present in various localities of Pakistan e.g., novel strains producing hydrolytic enzymes were isolated from hot springs and salt mines in Pakistan (Roohi et al., 2012, 2014; Zahoor et al., 2016). We are still exploring different microbial reservoirs to characterize novel extremophilic enzymes from sources such as hot springs, glaciers, deserts, salt mines, and coal mines located at Pakistan. Although there are few reports regarding microbial explorations in these areas, there is still a lot of work needed to identify novel microbial sources of bio-industrial importance (Afridi et al., 2019; Ali et al., 2016; Shah et al., 2017). Here, we report new amylase producing bacterial strains taken from the Shahdara springs located in the hilly area of MargallaIslamabad-Pakistan. The Shahdara springs have been explored for microbial flora, however, these springs have been rarely investigated for microbes producing enzymes. Total of 28 bacteria were primarily isolated from the Shahdara springs and screened for the amylase activity. The three best amylase producing bacteria were selected out of 22 amylase producers to check its growth and activity under different physical factors like $\mathrm{pH}$ and temperature.

\section{Materials and methods}

\section{Specimen collection and enrichment of bacterial isolates}

Freshwater samples $(n=25)$ were collected from different locations in the springs of Shahdara valley, Islamabad ( $31^{\circ} 37^{\prime} 16.0068^{\prime \prime} \mathrm{N}$ and $74^{\circ} 16^{\prime} 56.5104$ " E) in 2018. Temperature and $\mathrm{pH}$ at the time of sampling collection was approximately $22^{\circ} \mathrm{C}$ and $7-$ 8 , respectively. The samples in sterilized bottles were immediately transported to the microbiology laboratory of Kohat University of Science \& Technology (KUST), Kohat and preserved at $4{ }^{\circ} \mathrm{C}$ until further use. The bacterial isolation was carried out through a standard serial dilution technique. Moreover, enrichment was done using $2 \mathrm{ml}$ of bacterial culture into $10 \mathrm{ml}$ of LB broth and incubated at temperatures 40, 50, 55 and $60{ }^{\circ} \mathrm{C}$ for $24 \mathrm{~h}$. After that, $100 \mu \mathrm{l}$ of samples were diluted and spread onto LB agar and nutrient agar. The plates were then incubated at temperatures $40,50,55$, and $60{ }^{\circ} \mathrm{C}$ for 24 and $48 \mathrm{~h}$. The bacterial isolates were further purified based on colonial morphology. 


\section{Screening and identification of amylase producing bacteria}

All the isolated colonies were further streaked on the spot method on a starch agar plate and were incubated at $37^{\circ} \mathrm{C}$ for $24 \mathrm{~h}$. The incubated plates were checked for amylase activity by adding $1 \%$ iodine and $2 \%$ potassium iodide solution. The isolate that survived and produced a clear zone around the colony was considered as an amylase producing bacteria. Bacterial isolates giving the largest clear zones were taken for further studies. The bacterial isolates were characterized according to the standard procedure based on morphological and biochemical tests for initial identification that were further identified by 16S rRNA gene sequencing (Sen et al., 2014). Therefore, for molecular identification, bacterial DNA was extracted using Gene Jet Genomic DNA Purification Kit. Genomic DNA samples were subjected to PCR for the amplification of the 16S rRNA gene using universal primers (5-GGAGGCAGCAGTAGGGAATA-3) and (3TGACGGGCGGTGAGTACAAG-5). The PCR conditions were set as initial denaturation $\left(94{ }^{\circ} \mathrm{C}\right.$ for $\left.6 \mathrm{~min}\right)$, followed by annealing temperature $\left(56^{\circ} \mathrm{C}\right.$ for $\left.40 \mathrm{~s}\right)$ and extension $\left(72{ }^{\circ} \mathrm{C}\right.$ for $50 \mathrm{~s}$ ). The final extension was performed at $72{ }^{\circ} \mathrm{C}$ for $3 \mathrm{~min}$ for a total of 35 cycles. The PCR amplified product was sequenced using the commercial service of Advance Bioscience International (ABI). The sequence was BLAST searched on EZ-Biomedical server to get the exact nomenclature of the isolates. The phylogenetic tree was constructed with MEGA 6 using the neighbor-joining method with a bootstrap value of 1000 .

\section{Optimization of bacterial growth and amylase production}

The selected amylase producing bacterial isolates were optimized by the following factors such as $\mathrm{pH}$ and temperature in liquid media. The liquid medium was contained of starch peptone $\left(10 \mathrm{~g} / \mathrm{l}\right.$ each), yeast extract $(20 \mathrm{~g} / \mathrm{l}), \mathrm{KH}_{2} \mathrm{PO}_{4}(0.10 \mathrm{~g} / \mathrm{l}), \mathrm{CaCl}_{2} .2 \mathrm{H}_{2} \mathrm{O}(0.10$ $\mathrm{g} / \mathrm{l}), \mathrm{MgSO}_{4} .7 \mathrm{H}_{2} \mathrm{O}(0.50 \mathrm{~g} / \mathrm{l})$ and $\mathrm{FeSO}_{4} .7 \mathrm{H}_{2} \mathrm{O}(0.02 \mathrm{~g} / \mathrm{l})$ to evaluate amylase production. The effect of $\mathrm{pH}$ on bacterial growth and production was conducted in a flask containing the above liquid media by maintaining $\mathrm{pH}$ range of 3-11. While the effect of temperature was checked by incubating at different temperature ranges from $35,45,55,65$ and $75{ }^{\circ} \mathrm{C}$. The turbidity of bacterial culture was measured by spectrophotometer at $540 \mathrm{~nm}$ as amylase produced.

Bernfeld (1995) method is used to determine the activity of amylase (Bernfeld, 1995). The assay was performed in a test tube using enzyme extract $(1 \mathrm{ml}), 0.05 \mathrm{M}$ sodium phosphate buffer $(1 \mathrm{ml})$ at $\mathrm{pH} 7.0$ and $1 \%$ starch $(1 \mathrm{ml})$. The mixture was then incubated at $55^{\circ} \mathrm{C}$ for $15 \mathrm{~min}$ followed by the addition of $1 \mathrm{ml}$ of DNS reagent to stop reaction. The optical density of color produced was reported by spectrophotometer at $540 \mathrm{~nm}$ using maltose as standard. One unit of enzyme was defined as the amount of enzyme requires releasing one $\mu \mathrm{mol}$ of reducing sugar per minute by applying the following formula reported in literature (Singh et al., 2015):

$$
\text { Amylase Activity }(\mathrm{IU} / \mathrm{ml} / \mathrm{min})=\frac{\text { Activity of enzyme } \times 1000}{\text { Molecular weight of maltose } \times \text { Incubation time }}
$$

\section{Partial purification of amylase}

Ammonium sulfate precipitation method was used to partially purify crude amylase enzyme. The precipitation mixture was centrifuged at $4000 \mathrm{rpm}$ at $4{ }^{\circ} \mathrm{C}$ for $30 \mathrm{~min}$. The supernatant was discarded and protein pellet was dissolved in $5 \mathrm{ml}$ of phosphate buffer and store at $4{ }^{\circ} \mathrm{C}$ for further analysis. 


\section{Electrophoretic amylase separation}

The Laemmle method was used to determine the purity and molecular weight of partially purified amylase on $12 \%(\mathrm{w} / \mathrm{v})$ Sodium dodecyl polyacrylamide gel electrophoresis (SDS-PAGE) under reducing conditions. The enzyme was taken in eppendorf tube and loading dye was added. The solution was mixed gently. Both were heated in a water bath for $5 \mathrm{~min}$. The protein sample was loaded in each well along with standard protein ladder. The process was performed for $120 \mathrm{~min}$ at $120 \mathrm{~V}$ until the bromophenol blue reached to the bottom of the gel. Coomassie Brilliant blue solution was used to stain the gel for $30 \mathrm{~min}$ and the gel was de-stained for $2.5 \mathrm{~h}$.

\section{Characterization of partially purified amylase}

The activity of amylase enzyme was determined using a buffer of different $\mathrm{pH}$ range from 3 to 11 . Similarly, the temperature effect was studied by incubating at $35,45,55$, $65,75^{\circ} \mathrm{C}$ and amylase activity was measured as per the assay procedure.

\section{Statistical analysis}

All assays were performed in triplicate $(\mathrm{n}=3)$ and their means and standard errors were statistically analyzed using Graph Pad Prism Software.

\section{Results}

\section{Isolation and screening of amylase producing isolates}

In current study, total 28 bacterial isolates were isolated on the basis of their morphology using spread plate technique from Shahdara valley Islamabad, Pakistan. These isolates were further screened for their amylase activity on the basis of sizes of clear zones by applying 1\% iodine solution using starch agar media. Among these, 22 isolates showed amylase activity ranged from a small to large zone around the bacterial colony (Fig. 1A, B). The amylase activities based on clear zones around the colonies are also reported in previous literature (Padhiar and Kommu, 2016). On the basis of their maximum amylase activity on specific conditions, the strains such as S5, S13, and S17 were selected to proceed further for onward characterization.
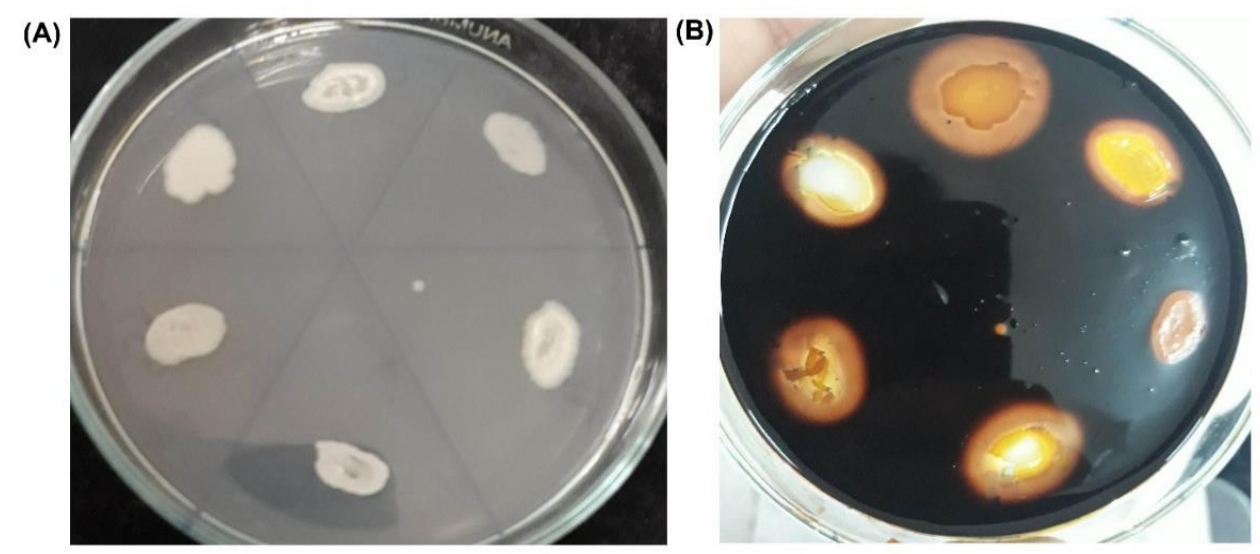

Figure 1. Amylase activity test. (A) Bacterial zone before addition of iodine and potassium iodide solution. (B) clear zone around the colonies after addition of iodine and potassium iodide solution 


\section{Morphological and molecular identification of the selected isolates}

The selected bacterial isolates were further subjected to gram staining and were observed as gram-positive rods and positive for spore staining. Based on their morphological and biochemical tests, the isolates were identified as Bacillus and Clostridium spp as described in Table 1. Moreover, 16S rRNA gene sequencing for these isolates revealed that the isolate S5, S13, and S17 have 97\% similarity with Paraclostridium benzoelyticum, Bacillus subtilis and Bacillus tequilensis respectively using phylogenetic analysis (Fig. 2A-C).

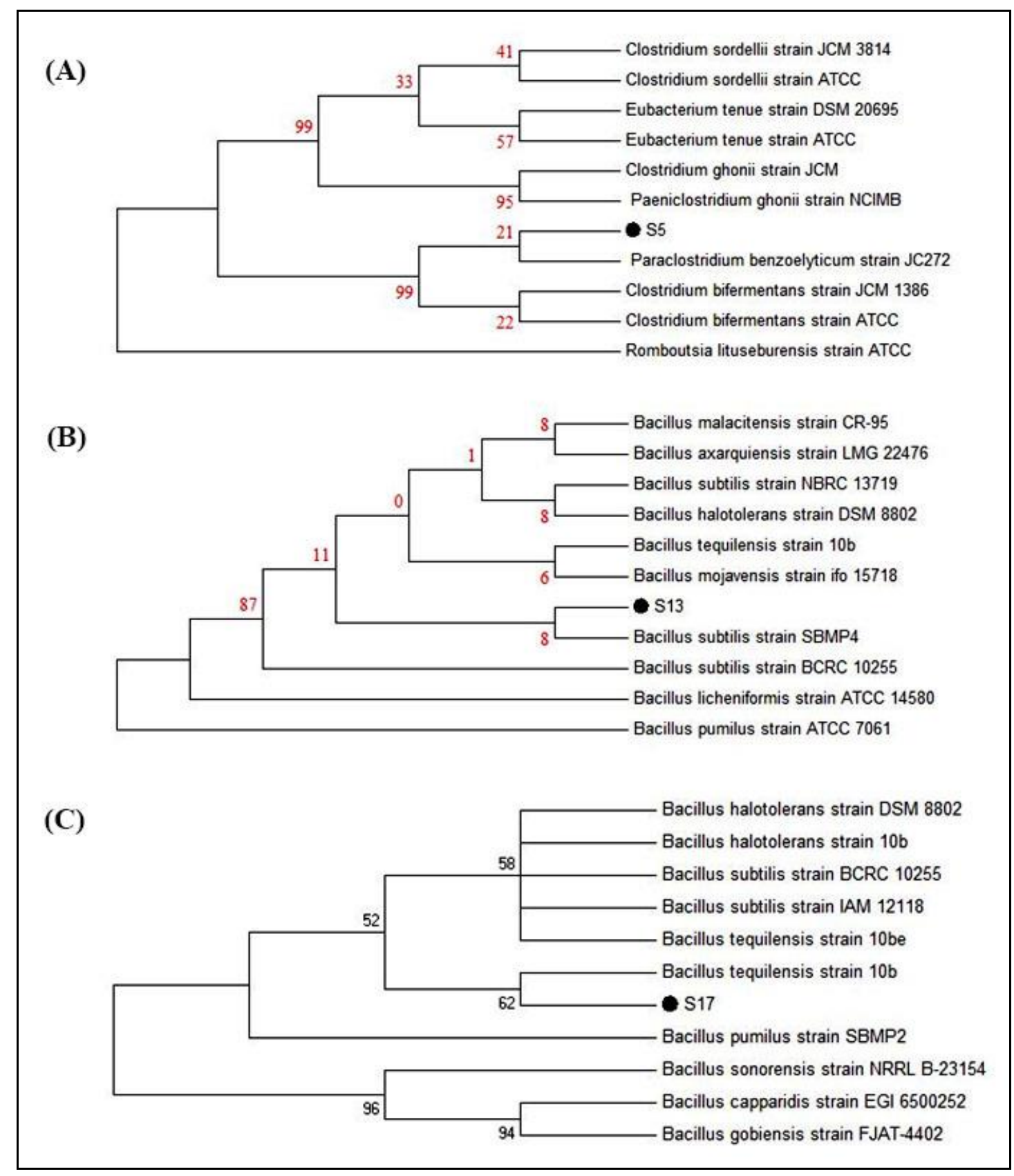

Figure 2. Phylogenetic tree of isolates from Shahdara springs. (A-C) Phylogenetic tree showing the interrelationships of isolates of S5, S13 and S17 and their close relatives inferred from $16 \mathrm{~S}$ rRNA gene sequence. (Evolutionary analysis was conducted in MEGA 6. Scale bar $=0.005$ changes per nucleotide position) 
Table 1. Tentative identification of the selected isolates $(n=3)$ on the basis of gram staining and different biochemical tests

\begin{tabular}{c|c|c|c}
\hline Variables & Strain 5 & Strain 13 & Strain 17 \\
\hline Morphology & Rods & Rods & Rods \\
Gram staining & + & + & + \\
Endspore staining & + & + & + \\
Oxidase & - & - & - \\
Glucose test & + & + & + \\
Urease test & + & + & + \\
Indole test & + & - & + \\
Citralase & + & + & - \\
Voges-Proskauer & - & - & - \\
Catalase & - & Bacillus & Bacillus \\
\hline Identification & Clostridium
\end{tabular}

\section{Analysis of bacterial growth and amylase production}

The selected isolates were subjected to variable temperature and $\mathrm{pH}$, in order to evaluate optimum bacterial growth as well as optimum amylase production. Among them, the Paraclostridium benzoelyticum strain S5 given the highest growth at $\mathrm{pH} 7$ while the highest production of amylase at $\mathrm{pH}$ 5. The growth and production were also checked for Bacillus subtilis strain. It was observed that the maximum growth and optimum production of amylase enzyme were at the same $\mathrm{pH}$, i.e. $\mathrm{pH}$ 5. However, Bacillus tequilensis showed the optimum growth at $\mathrm{pH} 6$ and amylase production at $\mathrm{pH} 8$. In addition, the temperature effect on the growth and production of all selected isolates were also checked. It was observed that the optimal temperature for growth of Paraclostridium benzoelyticum was $45^{\circ} \mathrm{C}$ and obtained a maximum yield of amylase at $55^{\circ} \mathrm{C}$. However, for the Bacillus subtilis and Bacillus tequilensis, the optimum temperature of bacterial growth and yield was the same and reported as $55^{\circ} \mathrm{C}($ Fig. $3 A-F)$.
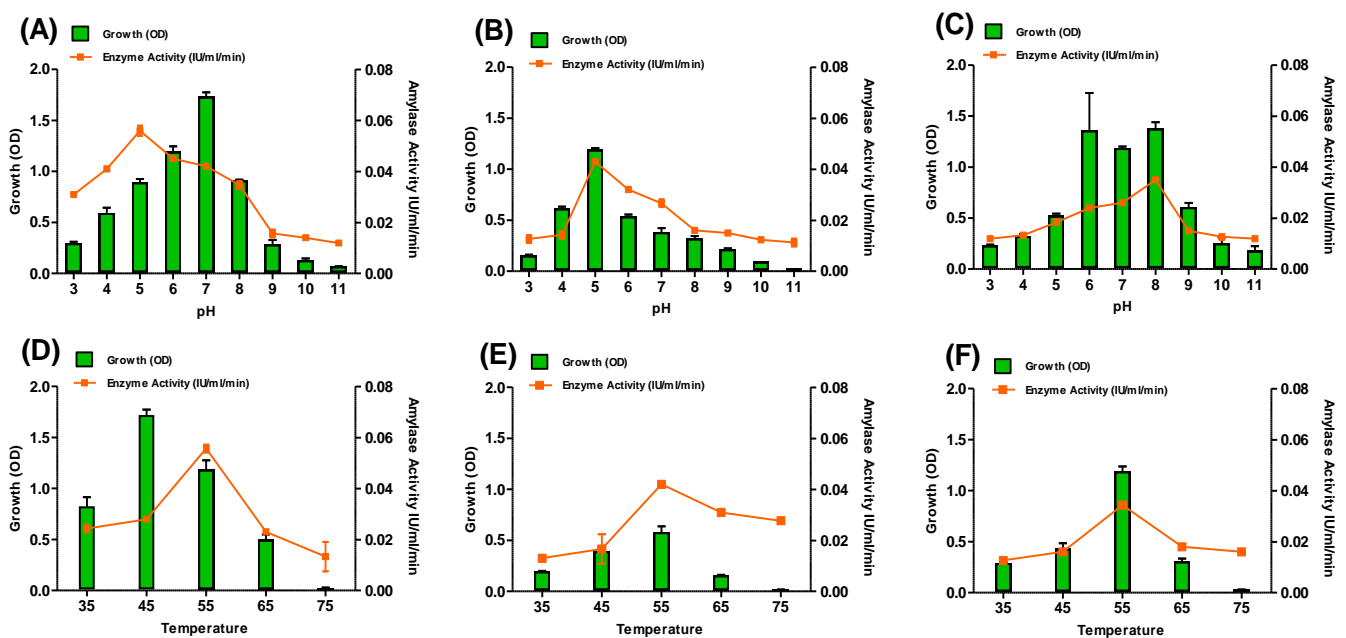

Figure 3. Effect of $p H$ and temperature on bacterial growth and amylase production. (A and D) growth and amylase production of isolate $S 5,(B$ and $E)$ growth and amylase production of isolate $S 13,(C$ and $F)$ growth and amylase production of isolate $S 17$ at different $\mathrm{pH}$ and temperature 


\section{SDS-PAGE analysis and activity of amylase enzymes}

Partial purification of amylase enzymes was performed using 80\% saturation of ammonium sulfate. The pellet was separated by SDS PAGE and the amylase enzymes of the strain Paraclostridium benzoelyticum (S5), Bacillus subtilis (strain S13) and Bacillus tequilensis (S17) had the molecular weight of $35 \mathrm{kDa}, 37 \mathrm{kDa}$, and $36 \mathrm{kDa}$, respectively (Fig. 4).

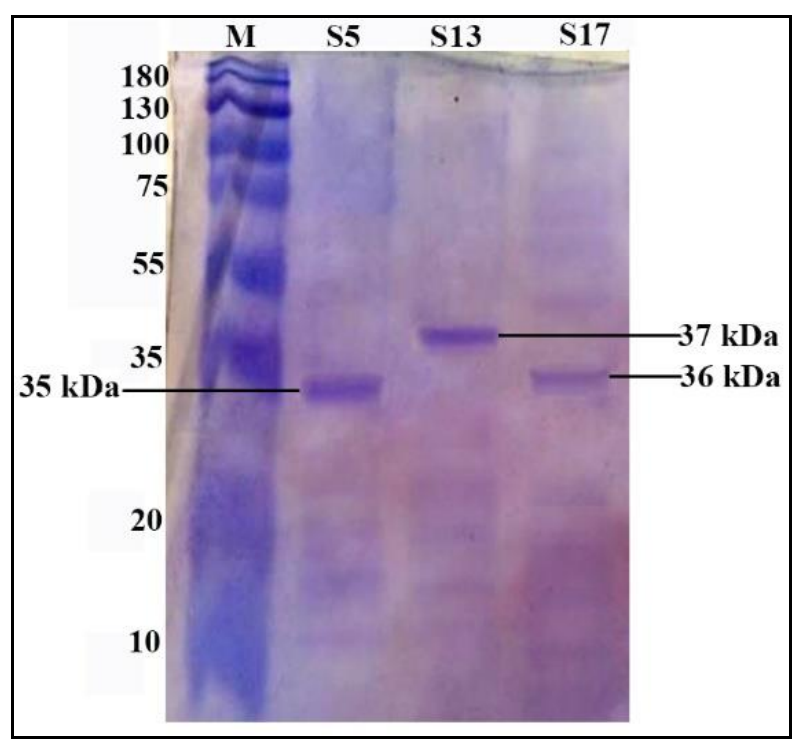

Figure 4. SDS-PAGE analysis of partially purified amylase enzymes extracted from isolates S5, S13, and S17

In order to find optimum conditions for amylase activity, the product of selected isolates was subjected to a gradient range of $\mathrm{pH}$ and temperature. The highest activity of amylase for both species Paraclostridium benzoelyticum strain (S5) and Bacillus subtilis strain (S13) was at $\mathrm{pH}$ 5. However, for Bacillus tequilensis strain (S17), the optimal $\mathrm{pH}$ for amylase activity was found in the ranges of $\mathrm{pH}$ 6-8. Moreover, the maximum amylolytic activity of all the three isolates was reported at the same temperature, i.e. $55^{\circ} \mathrm{C}$ (Fig. $\left.5 A, B\right)$.
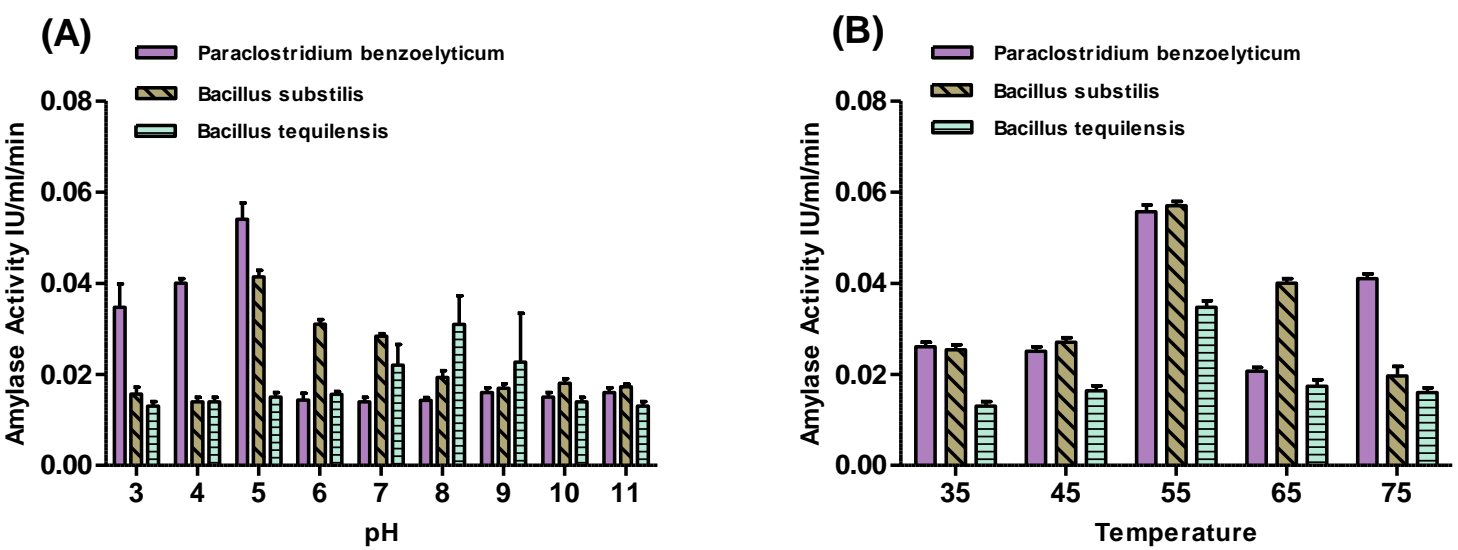

Figure 5. Effect of $\mathrm{pH}$ and temperature on amylases activity of selected bacterial isolates. (A) $\mathrm{pH}$ effect on amylase activity, $(B)$ temperature effect on amylase activity 


\section{Discussion}

Amylases are the most widely used enzymes in different industries for manufacturing purposes. In the food industry, amylase enzymes play a significant and leading role in hydrolysis of starch into dextrins and small polymers of glucose. In addition, amylases are widely applicable to other industries such as textile and pulp (Gupta et al., 2003). Microbial sources, for examples, bacteria, and fungi, are the most preferred sources to harvest amylase enzymes due to the ease of cultivation, shorter generation time, smaller space requirements and efficient purification procedures (Burhan et al., 2003). In this study, the amylase producing bacterial isolates are explored for the first time in the rarely explored Shahdara springs, Pakistan. In total, 28 bacteria were isolated and among these, 22 bacterial isolates showed amylase activity ranged from small to large zone around the bacterial colony. Three best amylase producing strains, S5, S13, and S17, were selected for onward characterization based on their high amylase activity, in other words, starch degradation potentials, as depicted in Figure 1A-B. The morphological and biochemical characteristics revealed differences in bacterial diversity of Shahdara springs. 16 sRNA gene sequencing provided the precise identifications of microbes, revealing that the three selected strains S5, S13 and S17 are Paraclostridium benzoelyticum, Bacillus subtilis and Bacillus tequilensis, respectively. The amylase enzymes collected in the pellet after ammonium sulfate precipitation was separated by SDS PAGE and three bands of similar sizes ranging from $35 \mathrm{kDa}$ to $37 \mathrm{kDa}$ were obtained on the gel. The molecular sizes of the amylases in the literature varied mainly depending on the microbial sources from which enzymes were purified. We have reported the bacterial amylase from a different source such as salt mines of Karak, which had a molecular weight of $50 \mathrm{kDa}$ (Shah et al., 2017).

Intriguingly, temperature and $\mathrm{pH}$ conditions for the highest bacterial growth did not always correspond to those of the highest amylase yield. The best bacterial growth and amylase yield of Paraclostridium benzoelyticum (S3) were at $\mathrm{pH} 7$ and 5. Bacillus tequilensis (S17) also revealed the maximum growth and enzyme production at different $\mathrm{pH}$ values, 6 and 8. Similar results in the same species were reported by Khan and Gupta (2011) They reported the best growth and enzyme production of Bacillus tequilensis were achieved at $\mathrm{pH} 7$ and 10, respectively (Khan and Gupta, 2011). However, the Bacillus subtilis (S13) showed the best growth and amylase production at the same pH 5 (Fig. 3A-F). In the previous work of our laboratory, the same condition for optimum growth and enzyme production of proteases produced by Pseudomonas aeruginosa strain collected from coal mines was reported (Afridi et al., 2019). Taken together, these results indicate that there is no direct relationship between the growth and production of enzymes.

In a similar fashion, the effect of temperature on amylase production and bacterial growth was evaluated as well. It is characterized that the Bacillus subtilis and Bacillus tequilensis strains have the maximum growth and enzyme production at the same temperature, $55{ }^{\circ} \mathrm{C}$. However, Paraclostridium benzoelyticum strain grew well at $45{ }^{\circ} \mathrm{C}$, whereas the optimum temperature for enzyme production was $55^{\circ} \mathrm{C}$ (Fig. 3A-F). The amylase enzymes activity has also been reported for Bacillus sp. WA21 at $55^{\circ} \mathrm{C}$ which is supported here by our findings (Wajeeha et al., 2011).

Furthermore, the amylase activity of the three isolates was studied on various $\mathrm{pH}$ and temperature conditions. The two isolates, Bacillus subtilis (S5) and Paraclostridium benzoelyticum (S13), showed the highest amylase activity in the same conditions, $\mathrm{pH} 5$ and $55{ }^{\circ} \mathrm{C}$ (Fig. 5A, B). This revealed the acidic and thermophilic nature of the amylase 
enzymes produced by these bacteria. The third isolate Bacillus tequilensis (S17) had the highest amylase activity at the same temperature, but the optimum $\mathrm{pH}$ was in a range of 6-8. These unique acid-stable and thermo-stable amylases can be used in unavoidable acidic and high temperature conditions frequently occurred in fermentation, food processing, and pharmaceutical manufacturing. Together, this study revealed that Shahdara springs are the rich source of microbial enzymes of diverse nature and of biotechnological importance.

\section{Conclusion and future studies}

In total, 22 amylase producing bacteria were isolated from the rarely explored Shahdara springs and the three best producers were identified and characterized as Paraclostridium benzoelyticum (S5), Bacillus subtilis (S13) and Bacillus tequilensis strain (S17). The two isolates Paraclostridium benzoelyticum (S5), and Bacillus subtilis (S13) have surprisingly revealed the same optimum conditions for amylase enzymes activity such as $\mathrm{pH} 5$ and temperature $55^{\circ} \mathrm{C}$. This revealed the acidic and thermophilic nature of amylases produced by these isolates which can be of high importance at acidic and high temperature operational conditions in bio-industrial applications. On the basis of previous studies, it has been recommended that most of the springs located in Pakistan, possessed valuable bacterial flora that need to be explored for enzymes using metagenomics-based approaches for various bio-industrial applications.

Acknowledgements. The authors are grateful to the Higher Education Commission of Pakistan for financial support and the Department of Biotechnology and Genetic Engineering, Kohat University of Science and Technology for providing laboratory facilities to carry out the present research work. This work was also supported by Research Assistance Program (2019) in the Incheon National University.

Conflict of interests. All authors declared no conflict of interests, and also the funding body had no role in the experiment design, methodology or data interpretation.

\section{REFERENCES}

[1] Afridi, M. I., Ali, N., Memon, A. R., Qasim, M., Jamal, Q., Khattak, B., Adnan, M., Khan, S. N., Ullah, A., Younas, F., Ullah, F. (2019): Protease producing Pseudomonas aeruginosa strain (IBC-2) from coal mines of Orakzai Agency, Pakistan. - Appl Ecol Env Res. 17(3): 6081-6093.

[2] Ali, I., Kanhayuwa, L., Rachdawong, S., Rakshit, S. K. (2013): Identification, phylogenetic analysis and characterization of obligate halophilic fungi isolated from a man-made solar saltern in Phetchaburi province, Thailand. - Annals of Microbiology 63(3): 887-895.

[3] Ali, N., Ullah, N., Qasim, M., Rahman, H., Khan, S. N., Sadiq, A., Adnan, M. (2016): Molecular characterization and growth optimization of halo-tolerant protease producing Bacillus Subtilis Strain BLK-1.5 isolated from salt mines of Karak, Pakistan. Extremophiles 20(4): 395-402.

[4] Bernfeld, P. (1995): Amylases $\alpha$ and $\beta$. - Meth. Enzymology. 1149-158.

[5] Burhan, A., Nisa, U., Gokhan, C., Omer, C., Ashabil, A., Osman, G. (2003): Enzymatic properties of a novel thermostable, thermophilic, alkaline and chelator resistant amylase from an alkaliphilic Bacillus sp. Isolate ANT-6. - Process Biochem. 38: 1397-1403.

[6] De Souza, P. M., De Oliveira Magalhaes, P. (2010): Application of microbial alphaamylase in industry - a review. - Braz J Microbiol. 41(4): 850-61. 
[7] Gopinath, S. C., Anbu, P., Arshad, M. K., Lakshmipriya, T., Voon, C. H., Hashim, U., Chinni, S. V. (2017): Biotechnological processes in microbial amylase production. Biomed Res Int. 20171272193.

[8] Gupta, R., Gigras, P., Mohapatra, H., Goswami, V. K., Chauhan, B. (2003): Microbial aamylases: a biotechnological perspective. - Process Biochem. 00(00): 1-18.

[9] Khan, I., Gupta, P. J. V. (2011): Thermo-alkaliphilic halotolerant detergent compatible protease(s) of Bacillus tequilensis MTCC 9585. - Afr. J. Microbiol. Res. 5(23): 39683975.

[10] Kim, S.-K., Toldrá, F. (2016): Marine Enzymes Biotechnology: Production and Industrial Applications, Part II - Marine Organisms Producing Enzymes. - Academic Press, Cambridge, MA.

[11] Li, S., Yang, X., Yang, S., Zhu, M., Wang, X. (2012): Technology prospecting on enzymes: application, marketing and engineering. - Comput Struct Biotechnol J. 2e201209017.

[12] Padhiar, A. R., Kommu, S. (2016): Isolation, characterization and optimization of bacteria producing amylase. - Int. J. Adv. Res. Biol. Sci. 3(7): 1-7.

[13] Parmar, D., Pandya, A. (2012): Characterization of amylase producing bacterial strain. Bull Environ Pharmacol Life Sci 1(6): 42-47.

[14] Patel, G., Patel, P., Patel, N. (2018): Purification and characterization of amylase produced by Halobacterium sp. GB24 isolated from marine National Park. - G. J. B. B. 7(3): 406-411.

[15] Roohi, A., Ahmed, I., Iqbal, M. M. J. (2012): Preliminary isolation and characterization of halotolerant and halophilic bacteria from salt mines of Karak, Pakistan. - Pak. J. Bot. 44(Special Issue March 2012): 365-370.

[16] Roohi, A., Ahmed, I., Khalid, N., Iqbal, M., Jamil, M. (2014): Isolation and phylogenetic identification of halotolerant/halophilic bacteria from the salt mines of Karak, Pakistan. Int. J. Agric. Biol. 16(3): 564-570.

[17] Sen, S. K., Mohapatra, S. K., Satpathy, S., Rao, G. T. V. (2010): Characterization of hot water spring source isolated clones of bacteria and their industrial applicability. - Int $\mathbf{J}$ Chem Res. 2(1): 1-7.

[18] Sen, S. K., Raut, S., Satpathy, S., Rout, P. R., Bandyopadhyay, B., Das Mohapatra, P. K. (2014): Characterizing novel thermophilic amylase producing bacteria from Taptapani hot spring, Odisha, India. - Jundishapur J Microbiol. 7(12): e11800.

[19] Shah, W., Ali, N., Ahmad, S., Qasim, M., Rahman, H., Ullah, S., Ullah, F., Khattak, B., Khan, M. D. (2017): Molecular characterization and growth optimization of halo-tolerant amylase producing bacteria isolated from salt mines of Karak, Pakistan. - Pure Appl. Biol. 6(1): 385-393.

[20] Singh, R., Kumar, M., Mittal, A., Mehta, P. K. (2016): Microbial enzymes: industrial progress in 21st century. -3 Biotech. 6(2): 174.

[21] Singh, V., Sharma, R., Sharma, P. (2015): Isolation, screening and optimization of amylase producing Bacillus sp. from soil. - Asian Pac. J. Health Sci. 2(3): 86-93.

[22] Suriya, J., Bharathiraja, S., Krishnan, M., Manivasagan, P., Kim, S. K. (2016): Marine microbial amylases: properties and applications. - Adv Food Nutr Res. 79161-177.

[23] Tango, M. S. A., Islam, M. R. (2002): Potential of extremophiles for biotechnological and petroleum applications. - Energy Sources 24(6): 543-559.

[24] Wajeeha, A., Asif, M., Rasool, S. A. (2011): Extracellular enzyme production by indigenous thermophilic bacteria: partial purification and characterization of $\alpha$-amylase by bacillus sp. WA21. - Pak. J. Bot. 43(2): 1045-1052.

[25] Zahoor, S., Javed, M. M., Babarl, M. E. (2016): Characterization of a novel hydrolytic enzyme producing thermophilic bacterium isolated from the hot spring of Azad KashmirPakistan. - Braz. Arch. Biol. Technol. 59: e16150662(1): 1-13. 